\title{
Pengaruh Kemasan Aluminium Foil dan Botol Kaca terhadap Umur Simpan Abon Ikan Tongkol (Euthynnus affinis) dengan Pendekatan Metode Arrhenius
}

\author{
(Aluminium Foil and Glass Bottle Packaging Effect for Mackerel Tuna Floss Shelf Life \\ with Arrhenius Method Approach)
}

\author{
Wahyu Afdillah ${ }^{1}$, Ismail Sulaiman ${ }^{1}$, Martunis ${ }^{1}$ \\ ${ }^{1}$ Program Studi Teknologi Hasil Pertanian, Fakultas Pertanian, Universitas Syiah Kuala
}

\begin{abstract}
Abstrak. Penelitian ini bertujuan untuk mengetahui pengaruh kemasan aluminium foil dan botol kaca terhadap umur simpan abon ikan tongkol. Penelitian ini menggunakan metode Arrhenius dimana faktor pertamanya yaitu jenis kemasan $(\mathrm{K})$ yang terdiri dari dua taraf yaitu aluminium foil dan botol kaca. Faktor kedua yaitu suhu (S) dengan 3 taraf yaitu $30^{\circ} \mathrm{C}, 40^{\circ} \mathrm{C}$ dan $50^{\circ} \mathrm{C}$. Faktor ketiga yaitu lama penyimpanan dengan 5 taraf yaitu 0 hari, 7 hari, 14 hari, 21 hari dan 28 hari. Setiap perlakuan dilakukan pengulangan sebanyak 2 kali ulangan sehingga diperoleh 60 satuan percobaan. Hasil penelitian menunjukkan bahwa pada ordo nol, abon yang dikemas aluminium foil pada suhu $30^{\circ} \mathrm{C}, 40^{\circ} \mathrm{C}$ dan $50^{\circ} \mathrm{C}$ berturut-turut menghasilkan umur simpan selama 61 hari, 41 hari dan 28 hari, sedangkan abon yang dikemas botol kaca pada suhu $30^{\circ} \mathrm{C}, 40^{\circ} \mathrm{C}$ dan $50^{\circ} \mathrm{C}$ berturut-turut menghasilkan umur simpan selama 72 hari, 42 hari dan 26 hari. Pada ordo satu, abon yang dikemas aluminium foil pada suhu $30^{\circ} \mathrm{C}, 40^{\circ} \mathrm{C}$ dan $50^{\circ} \mathrm{C}$ berturut-turut menghasilkan umur simpan selama 116 hari, 85 hari dan 63 hari, sedangkan abon yang dikemas botol kaca pada suhu $30^{\circ} \mathrm{C}, 40^{\circ} \mathrm{C}$ dan $50^{\circ} \mathrm{C}$ berturut-turut menghasilkan umur simpan selama 194 hari, 123 hari dan 80 hari. Persamaan order aluminium foil yang dikemas nol adalah y $=$ $3702,6 x+6,924$ dan dikemas dengan botol kaca adalah $y=-5077,9 x+10,9191$. Sedangkan persamaan urutan satu dikemas dengan aluminium foil adalah $\mathrm{y}=-2823.5 \mathrm{x}+4.9702$ dan dikemas dengan botol kaca adalah $\mathrm{y}=-$ $4312.3 x+9.4082$.
\end{abstract}

Kata Kunci: ikan tongkol, abon ikan, umur simpan, botol kaca

\begin{abstract}
This study aimed to determine the effect of aluminum foil and glass bottle on the shelf life of tuna fish floss meat. This research used Arrhenius method where the first factor was packaging type (K) consisting of aluminum foil and glass bottle. The second factor was temperature (S) with 3 levels which were at $30^{\circ} \mathrm{C}, 40^{\circ} \mathrm{C}$ and $50^{\circ} \mathrm{C}$. The third factor was the storage period with 5 levels which were 0 days, 7 days, 14 days, 21 days and 28 days. Each treatment was repeated twice so the total was 60 units. The results showed that in the ordo zero, the shelf lifes of floss meat packed with aluminum foil at temperature $30^{\circ} \mathrm{C}, 40^{\circ} \mathrm{C}$ and $50^{\circ} \mathrm{C}$ were 61 days, 41 days and 28 days respectively, whereas the glass bottle obtained 72 days, 42 days and 26 days respectively. In the ordo one of floss meat packed with aluminum foil at $30^{\circ} \mathrm{C}, 40^{\circ} \mathrm{C}$ and $50^{\circ} \mathrm{C}$ respectively obtain shelf life for 116 days, 85 days and 63 days, whereas floss meat packed with glass bottles obtain shelf life 194 days, 123 days and 80 days. The equation of ordo zero packed aluminium foil is $\mathrm{y}=-3702.6 \mathrm{x}+6.924$ and packed with glass bottle is $\mathrm{y}=$ - 5077.9x +10.9191 . Whereas equation of ordo one packed with aluminium foil is $y=-2823.5 x+4.9702$ and packed with glass bottle is $\mathrm{y}=-4312.3 \mathrm{x}+9.4082$.
\end{abstract}

Keywords: Floss meat, mackerel tuna fish, aluminium foil, glass bottle, shelf life.

Corresponding author: raja_acehrayeuk@unsyiah.ac.id

JIM Pertanian - THP, Vol. 3, No. 3, Agustus 2018: 185-193 


\section{PENDAHULUAN}

Ikan merupakan bahan pangan hewani yang memiliki kandungan gizi tinggi seperti protein, lemak, mineral dan vitamin yang sangat dibutuhkan oleh manusia. Masyarakat Indonesia banyak mengkonsumsi ikan karena tersebar luas di perairan Indonesia. Namun ikan juga tergolong bahan pangan yang mudah rusak dan cepat mengalami pembusukan. Upaya pencegahan untuk mengatasi proses pembusukan dapat dilakukan dengan cara pengawetan dan pengolahan dengan menggunakan berbagai metode yang diperlukan.

Abon ikan merupakan jenis makanan olahan ikan yang diberi bumbu, diolah dengan cara perebusan dan penggorengan. Produk yang dihasilkan mempunyai bentuk lembut, rasa enak, aroma khas, dan mempunyai daya awet yang relatif lama. Sementara emenurut Karyono dan Wachid (1982) abon ikan adalah produk olahan hasil perikanan yang dibuat dari daging ikan, melalui kombinasi dari proses penggilingan, penggorengan, pengeringan dengan cara menggoreng, serta penambahan bahan pembantu dan bahan penyedap terhadap daging ikan.

Pengemasan pada bahan pangan merupakan suatu cara untuk mencegah kontaminasi dari lingkungan luar produk. Suatu bahan pangan harus dikemas dengan baik agar sampai ke tangan konsumen dalam kondisi yang baik pula. Selama ini pengemasan abon ikan pada industri - industri kecil, khususnya di daerah Aceh dikemas menggunakan kemasan plastik yang ditutup dengan sealer. Bahan pengemas plastik ini memiliki lapisan yang tipis dan berpori besar. Sehingga metode pengemasan seperti ini dapat mengurangi umur simpan abon dan cepat mengalami proses ketengikan akibat oksidasi lemak yang terjadi.

Umur simpan dan mutu abon ikan sangat berpengaruh terhadap pengemasan. Sehingga perlu dilakukan pengemasan yang baik meliputi jenis dan prosesnya. Menurut peneltitian Tridiyani (2012), umur simpan abon ikan marlin (Istiophorus sp) yang dikemas plastik metode non vakum suhu $35^{\circ} \mathrm{C}$ menghasilkan umur simpan selama 119 hari dan dengan metode vakum menghasilkan umur simpan selama 224 hari. Namun jenis kemasan alumunium foil dan botol kaca perlu dilakukan pengujian karena sifatnya yang lebih tebal dan kuat dibandingkan dengan kemasan plastik.

Pada penelitian ini abon ikan dikemas menggunakan kemasan alumunium foil dan botol kaca. Kemudian abon ikan disimpan selama 28 hari pada suhu $30^{\circ} \mathrm{C}, 40^{\circ} \mathrm{C}$ dan $50^{\circ} \mathrm{C}$ dan dilakukan perhitungan untuk menduga umur simpan menggunakan Accelerated Shelf-Life Testing (ASLT) melalui persamaan Arrhenius. Metode ini merekayasa suatu kondisi penyimpanan produk yang dapat mempercepat laju penurunan mutu. Perbedaan suhu yang digunakan untuk menentukan perubahan mutu selama penyimpanan sehingga diketahui pengaruhnya terhadap umur simpan.

\section{METODE PENELITIAN}

Penelitian ini dilaksanakan pada bulan Agustus - September 2017 di Laboratorium Rekayasa Proses Pangan dan Industri, Laboratorium Mikrobiologi Industri, Laboratorium Uji Sensori, Laboratorium Analisis Pangan dan Hasil Pertanian Jurusan Teknologi Hasil Pertanian dan Laboratorium Ilmu Teknologi Benih jurusan Agrotekh Fakultas Pertanian, Universitas Syiah Kuala.

Pengaruh Kemasan Aluminium Foil Dan Botol Kaca Terhadap Umur Simpan Abon Ikan Tongkol (Euthynnus Affinis) Dengan Pendekatan Metode Arrhenius (Wahyu Afdillah, Ismail Sulaiman, Martunis)

Jurnal Ilmiah Mahasiswa Pertanian Unsyiah, Vol. 3, No. 3, Agustus 2018: 185-193 


\section{Bahan dan Alat}

Alat-alat yang digunakan pada penelitian pembuatan abon ikan yaitu pisau, kompor, wajan, dandang, timbangan, blender, oven, hidrolik press. Alat-alat untuk analisis beaker glass, tabung reaksi, pipet volume, pipet tetes, desikator, cawan petri, inkubator, tisu, autoklaf, timbangan analitik, batang pengaduk, gelas ukur, erlenmayer dan Quebec Colony Counter. Bahan yang digunakan dalam penelitian ini terdiri dari bahan utama dan bahan tambahan serta beberapa bahan kimia. Bahan utama yang digunakan adalah ikan tongkol. Bahan tambahan terdiri dari serai 3 potong, daun salam 5 lembar, bawang merah 100 gr, bawang putih 15 gr, garam 5 gr, ketumbar 1,8 gr, santan $400 \mathrm{ml}$. Bahan analisis yaitu $\mathrm{H}_{2} \mathrm{SO}_{4}$, reagen $\mathrm{TBA}, \mathrm{N}_{\mathrm{a}} \mathrm{OH}$, HCL, Indikator PP, aquadest, n-Heksan, media PCA (Plate Count Agar), aquades, alkohol, larutan buffer dan kertas label, bahan pengemas yang digunakan aluminium foil dan botol kaca. meter.

\section{Rancangan Penelitian}

Penelitian Penelitian ini dilakukan dengan menggunakan metode ASLT (accelerated shelf-life testing) arrhenius. Pendugaan umur simpan ini ditentukan melalui perubahan mutu abon ikan berdasarkan dua faktor. Faktor I adalah jenis kemasan yang terdiri dari 2 taraf yaitu: $\mathrm{K} 1=$ aluminium foil dan $\mathrm{K} 2=$ botol kaca. Faktor II adalah suhu penyimpanan terdiri atas 3 taraf yaitu: $\mathrm{S} 1=30^{\circ} \mathrm{C}, \mathrm{S} 2=40^{\circ} \mathrm{C}$ dan $\mathrm{S} 3=50^{\circ} \mathrm{C}$. Analisis dilakukan selama penyimpanan (hari) terdiri atas 5 taraf yaitu : $\mathrm{P} 0=0$ hari, $\mathrm{P} 1=7$ hari, $\mathrm{P} 2=14$ hari, $\mathrm{P} 3=21$ hari dan $\mathrm{P} 4=28$ hari. Setiap kombinasi jenis kemasan dan suhu penyimpanan dilakukan dengan 2 kali ulangan. Dengan demikian terdapat 30 kombinasi perlakuan maka diperoleh 60 satuan percobaan.

\section{Prosedur Penelitian}

Pembuatan abon ikan pada penelitian ini dimulai dari tahap penyiangan ikan, dibuang kepala, ekor dan sisik lalu dilakukan pengukusan. Air dimasukkan dalam kukusan dengan perbandingan air dan ikan sebesar 3:1. Kukusan dipanaskan hingga air mendidih. Setelah air mendidih, ikan tersebut disusun dalam dandang dan dikukus pada suhu $\pm 70^{\circ} \mathrm{C}$ selama \pm 50 menit. Daging yang telah lunak disuir halus dan dimasukkan kedalam wajan penyangraian. Suiran daging diaduk merata sampai 3 jam. Abon yang telah disangrai lalu ditiriskan dan dicampur dengan bawang goreng. Abon dikemas menggunakan jenis kemasan aluminium foil dan botol kaca yang ditutup dengan rapat. Abon yang telah dikemas disimpan pada suhu $30^{\circ} \mathrm{C}, 40^{\circ} \mathrm{C}$, dan $50^{\circ} \mathrm{C}$ selama 28 hari.

\section{Analisis}

Analisis yang akan dilakukan pada abon ikan meliputi kadar air, total mikroba dan uji ketengikan TBA. Kemudian juga dilakukan uji organoleptik deskriptif meliputi warna, aroma, dan tekstur. Selanjutnya produk abon ikan dilakukan pendugaan umur simpan dengan metode Arrhenius.

Pengaruh Kemasan Aluminium Foil Dan Botol Kaca Terhadap Umur Simpan Abon Ikan Tongkol (Euthynnus Affinis) Dengan Pendekatan Metode Arrhenius (Wahyu Afdillah, Ismail Sulaiman, Martunis)

Jurnal Ilmiah Mahasiswa Pertanian Unsyiah, Vol. 3, No. 3, Agustus 2018: 185-193 


\title{
HASIL DAN PEMBAHASAN
}

\begin{abstract}
Abon Ikan
Prosedur pembuatan abon ikan tongkol (Euthynnus affinis) dalam penelitian ini berdasarkan dari penelitian Huthaimah (2017). Pada penelititan ini digunakan jenis kemasan alumunium foil dan botol kaca pada masing-masing suhu penyimpanan $30{ }^{\circ} \mathrm{C}, 40{ }^{\circ} \mathrm{C}$, dan 50 ${ }^{\circ} \mathrm{C}$ selama 28 hari yang pada setiap hari ke-1, 7, 14, 21 dan 28 dilakukan analisis untuk melihat umur simpan abon.
\end{abstract}

\section{Kadar Air}

Dari Gambar 1 dan 2 dapat disimpulkan bahwa kadar air abon ikan terus menurun selama penyimpanan. Nilai awal kadar air sebesar 6,9\% dan setelah 28 hari disimpan dikemas aluminium foil kadar air berubah menjadi 5,91\%, sedangkan kadar air yang dikemas botol kaca menjadi 6,60\%. Hal ini menunjukkan bahwa kadar air menurun sebesar 1,09\% pada kemasan aluminium foil dan pada kemasan botol kaca hanya sebesar 0,3\%. Hal ini sudah sangat baik karena menurut SII No. 0368-80, 03668-85 untuk produk abon ikan maksimum kadar air sebesar $10 \%$.

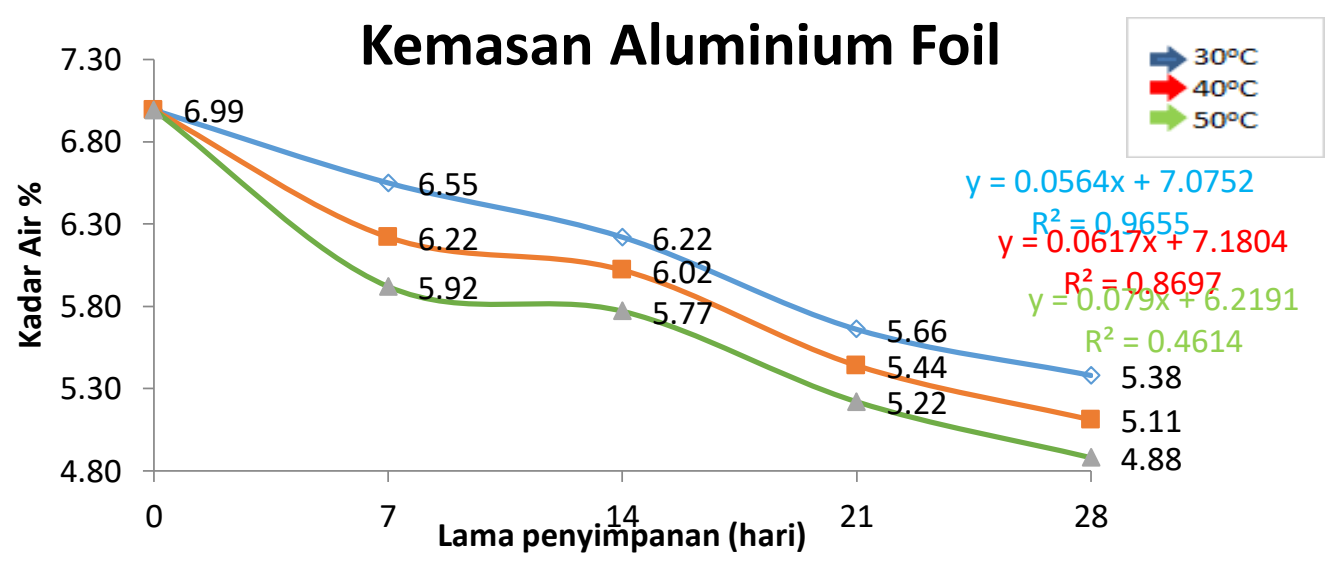

Gambar 1. Grafik nilai kadar air abon ikan kemasan aluminium foil pada berbagai suhu dan lama penyimpanan

Abon ikan yang dikemas botol kaca lebih mampu menahan uap air daripada kemasan aluminium foil. Kadar air dapat terhalang baik oleh kemasan botol kaca daripada kemasan aluminium foil. Hal ini dikarenakan botol kaca memiliki dinding yang lebih tebal dengan poripori yang lebih kecil daripada aluminium foil. Menurut Bray (2001) titik lebur pasir silika sangat tinggi mencapai $1700{ }^{\circ} \mathrm{C}$ lalu didinginkan sehingga membentuk kaca padat dengan kerapatan yang tinggi, dibandingkan dengan titik lebur aluminium hanya $660^{\circ} \mathrm{C}$ lalu dicetak menjadi aluminium foil dengan lapisan - lapisan tipis yang rapuh.

Pengaruh Kemasan Aluminium Foil Dan Botol Kaca Terhadap Umur Simpan Abon Ikan Tongkol (Euthynnus Affinis) Dengan Pendekatan Metode Arrhenius (Wahyu Afdillah, Ismail Sulaiman, Martunis)

Jurnal Ilmiah Mahasiswa Pertanian Unsyiah, Vol. 3, No. 3, Agustus 2018: 185-193 


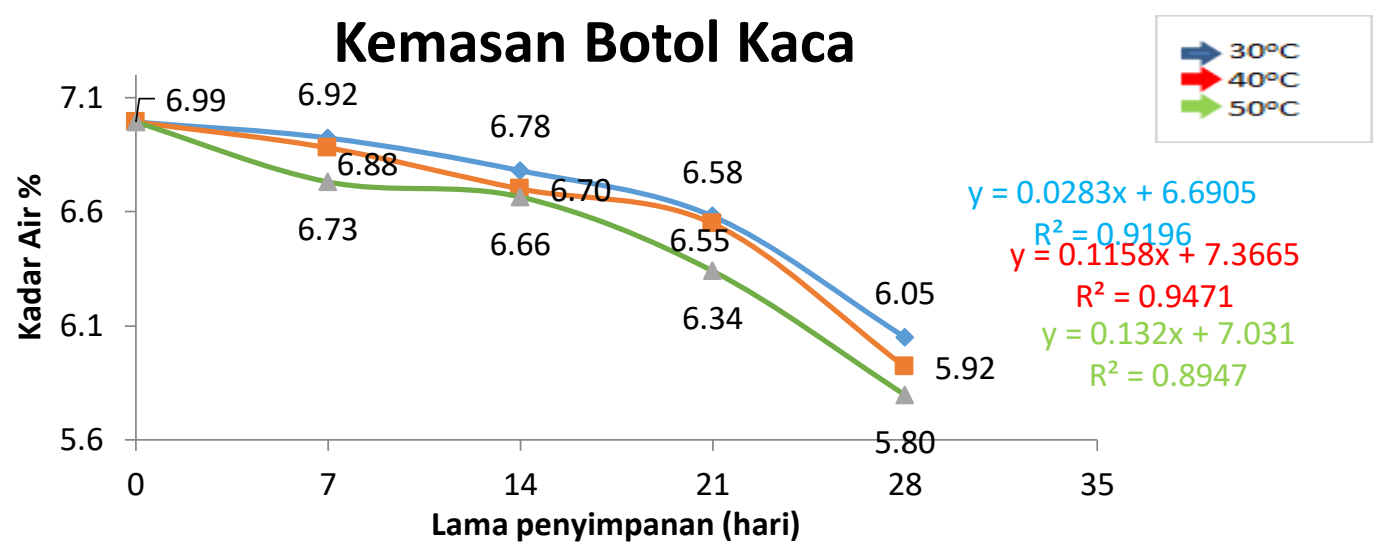

Gambar 2. Grafik nilai kadar air abon ikan kemasan botol kaca pada berbagai suhu dan lama Penyimpanan.

\section{Uji Ketengikan TBA}

Dari Gambar 3 dan 4 dapat disimpulkan bahwa analisis ketengikan menggunakan TBA (thiobarbituric acid) terus terjadi peningkatan selama penyimpanan 28 hari. Abon yang dikemas oleh aluminium foil pada hari ke 28 dengan suhu $30^{\circ} \mathrm{C}$ memiliki nilai TBA sebesar 0.44 , pada suhu $40^{\circ} \mathrm{C}$ memiliki nilai TBA sebesar 0.50 dan pada suhu $50^{\circ} \mathrm{C}$ memiliki nilai TBA sebesar 0.58 . Namun pada abon yang dikemas oleh botol kaca pada suhu $30^{\circ} \mathrm{C}$ memiliki nilai TBA yang lebih rendah dari kemasan aluminium foil yaitu sebesar 0.39 , pada suhu $40^{\circ} \mathrm{C}$ nilai TBA sebesar 0.48 dan pada suhu $50^{\circ} \mathrm{C}$ memiliki nilai TBA sebesar 0.53 . Nilai awal TBA pada hari ke-1 yaitu 0.32 dan terjadi kenaikan sebesar 0.26 pada kemasan aluminium foil dan 0.21 pada kemasan botol kaca. Abon yang dikemas oleh botol kaca memiliki nilai TBA relatif lebih rendah terhadap abon yang dikemas oleh aluminium foil.

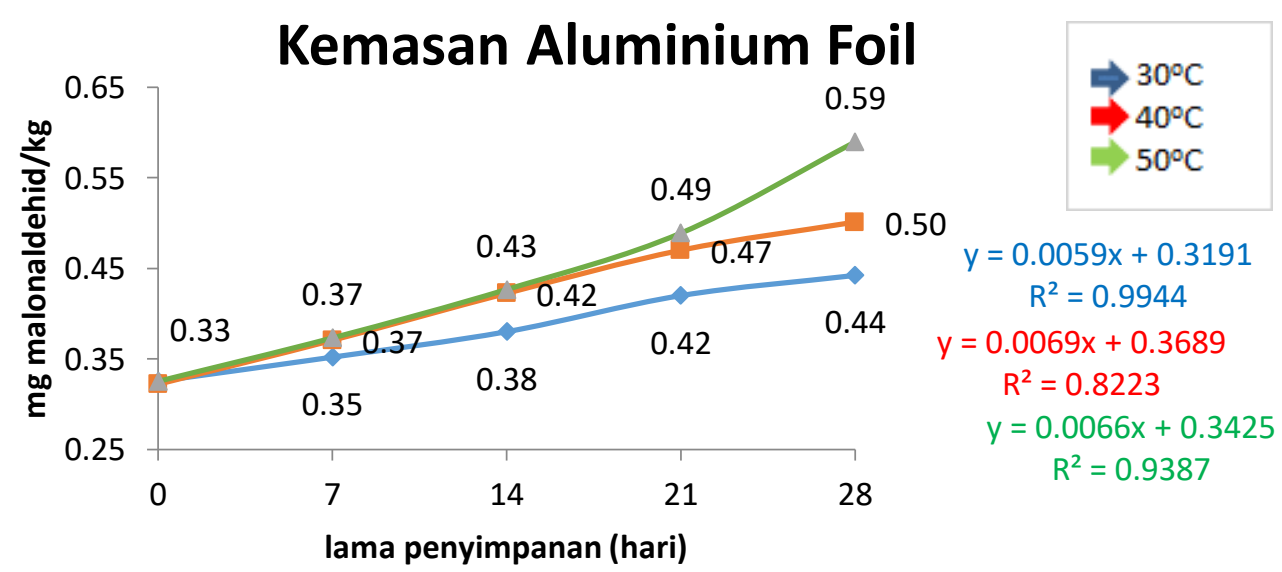

Gambar 3. Grafik nilai TBA abon ikan kemasan aluminium foil pada berbagai suhu dan lama penyimpanan

Pengaruh Kemasan Aluminium Foil Dan Botol Kaca Terhadap Umur Simpan Abon Ikan Tongkol (Euthynnus Affinis) Dengan Pendekatan Metode Arrhenius (Wahyu Afdillah, Ismail Sulaiman, Martunis)

Jurnal Ilmiah Mahasiswa Pertanian Unsyiah, Vol. 3, No. 3, Agustus 2018: 185-193 


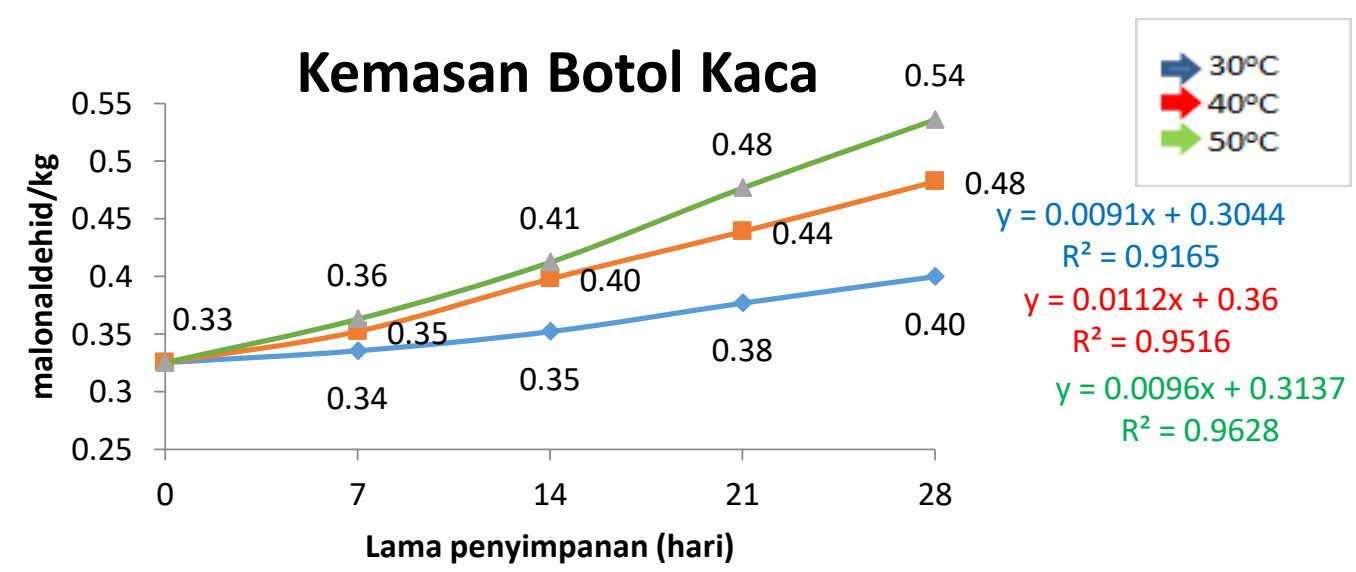

Gambar 4. Grafik nilai TBA abon ikan kemasan aluminium foil pada berbagai suhu dan lama penyimpanan

Dari kedua jenis kemasan abon membuktikan bahwa nilai kerusakan lemak pada aluminium foil lebih tinggi dibandingkan kemasan botol kaca. Hal ini sesuai dengan penelitian Rosalina (2009) bahwa botol kaca mampu menahan suhu dan udara lebih baik dibandingkan dengan aluminium foil karena ketebalan dan kerapatannya lebih tinggi. Sehingga kerusakan lemak abon di dalam kemasan dapat dicegah lebih baik dengan kemasan botol kaca.

\section{Total Mikroba}

Dari Gambar 5 dan 6 dapat diambil kesimpulan bahwa pertumbuhan mikroba terus meningkat selama pentyimpanan 28 hari. analisis total mikroba hari ke-0 tidak ditumbuhi mikroba pada kedua jenis kemasan karena suhu penyangraian yang tinggi saat proses pembuatan abon. Pertumbuhan mikroba terus meningkat selama penyimpanan 28 hari. Mikroba yang tumbuh di dalam kemasan aluminium foil sebanyak $5,2 \times 10^{7}$ rataan koloni dan di dalam kemasan botol kaca hanya $1,5 \times 10^{7}$ rataan koloni. Koloni mikroba terbanyak di dalam kemasan aluminium foil yaitu pada hari ke-28 suhu $30^{\circ} \mathrm{C}$ sebanyak $26 \times 10^{7}$ koloni dan di dalam kemasan botol kaca sebanyak $6 \times 10^{7}$ koloni pada hari ke-21 dan 28 suhu $30^{\circ} \mathrm{C}$.

Jenis kemasan yang lebih mampu menurunkan jumlah mikroba dilihat dari faktor pertumbuhan yang berpengaruh, adapun kemasan aluminium foil kurang baik untuk mengurangi jumlah mikroba karena kerapatan bahan lebih rendah dibandingkan botol kaca. Sehingga mikroba lebih banyak tumbuh di dalam kemasan aluminium foil akibat udara dan suhu. Sesuai dengan pernyataan Fardiaz (1992) bahwa pertumbuhan mikroba dipengaruhi oleh faktor internal berupa nutrisi dan faktor eksternal berupa suhu, tekanan, udara dan faktor pengolahan.

Pengaruh Kemasan Aluminium Foil Dan Botol Kaca Terhadap Umur Simpan Abon Ikan Tongkol (Euthynnus Affinis) Dengan Pendekatan Metode Arrhenius (Wahyu Afdillah, Ismail Sulaiman, Martunis)

Jurnal Ilmiah Mahasiswa Pertanian Unsyiah, Vol. 3, No. 3, Agustus 2018: 185-193 


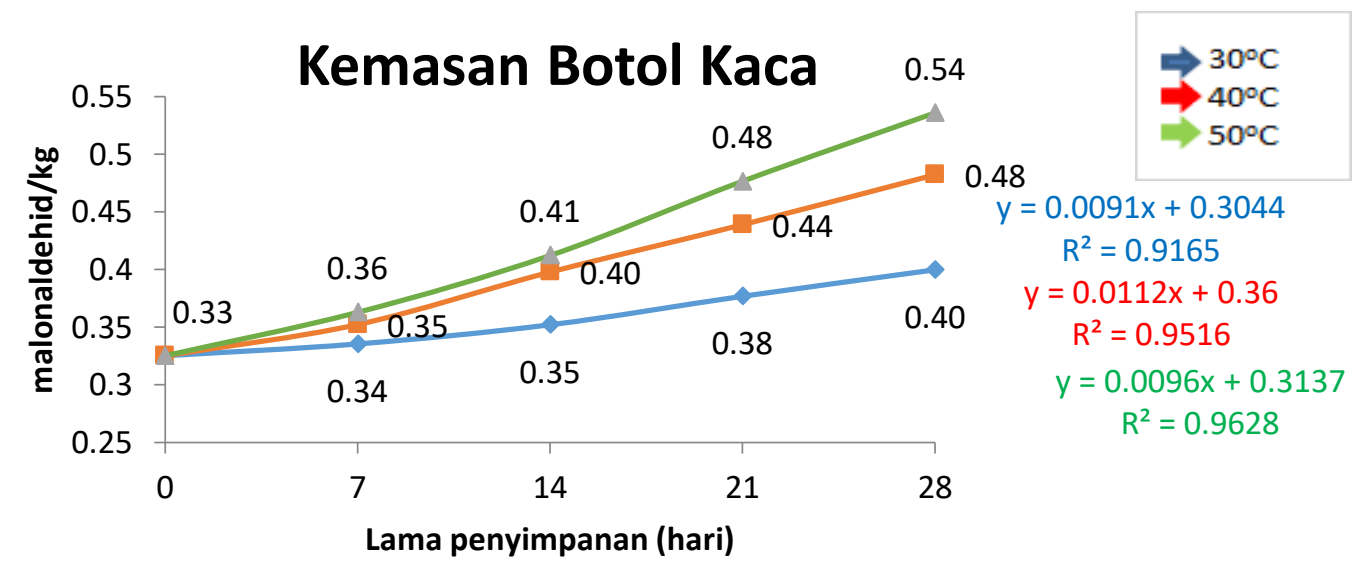

Gambar 5. Grafik nilai total mikroba abon ikan kemasan aluminium foil pada berbagai suhu dan lama penyimpanan
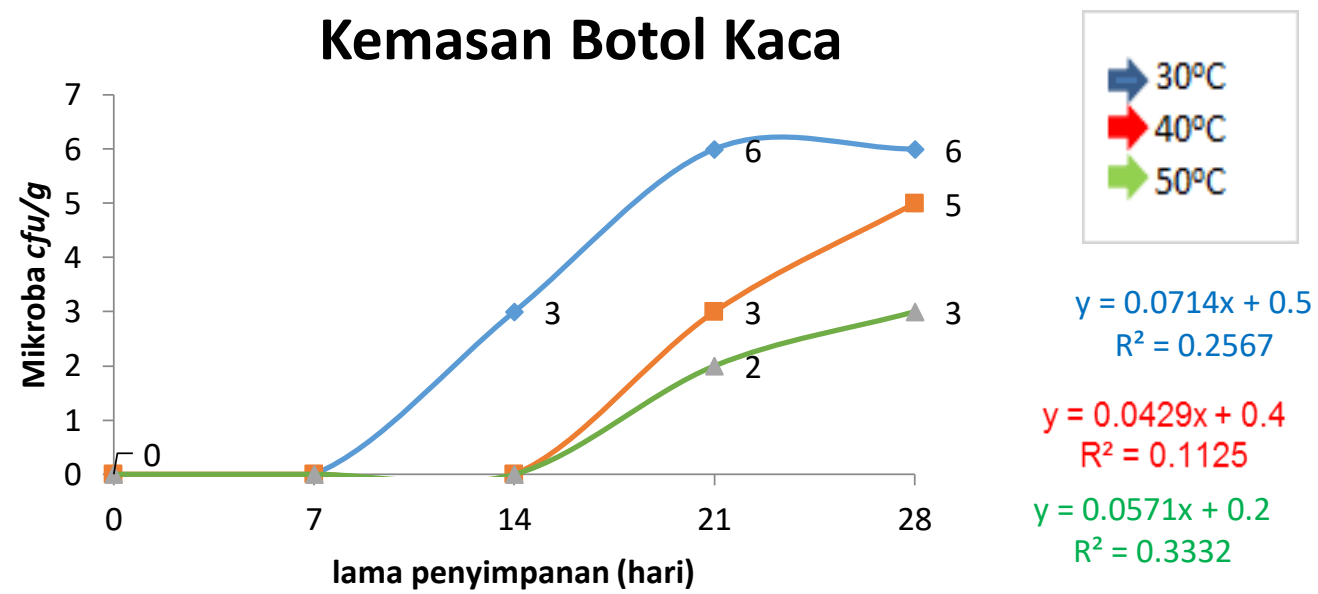

Gambar 6. Grafik nilai total mikroba abon ikan kemasan botol kaca pada berbagai suhu dan lama penyimpanan

\section{Perhitungan Umur Simpan Abon Ikan}

Analisis umur simpan abon ikan dilakukan dengan metode Arrhenius. Pada dasarnya Arrhenius menggunakan sistem percepatan laju kerusakan. Faktor yang sangat berpengaruh pada perubahan mutu untuk mempercepat laju kerusakan adalah suhu. Digunakan suhu $30^{\circ} \mathrm{C}$, $40^{\circ} \mathrm{C}$ dan $50^{\circ} \mathrm{C}$ untuk mempercepat laju kerusakan mutu selama penyimpanan.

Kerusakan mutu abon terjadi akibat nilai TBA yang tinggi sehingga menyebabkan kerusakan lemak dan abon menjadi beraroma tengik. Nilai TBA yang didapatkan selama penyimpanan diplotkan terhadap lama penyimpanan pada masing-masing ordo yaitu ordo nol

Pengaruh Kemasan Aluminium Foil Dan Botol Kaca Terhadap Umur Simpan Abon Ikan Tongkol (Euthynnus Affinis) Dengan Pendekatan Metode Arrhenius (Wahyu Afdillah, Ismail Sulaiman, Martunis)

Jurnal Ilmiah Mahasiswa Pertanian Unsyiah, Vol. 3, No. 3, Agustus 2018: 185-193 
dan ordo satu. sehingga diperoleh nilai slope yang merupakan nilai konstanta kecepatan reaksi dari masing-masing suhu penyimpanan selama 28 hari.

Berdasarkan perhitungan model Arrhenius diperoleh bahwa umur simpan abon ikan pada ordo nol suhu $30^{\circ} \mathrm{C}$ menggunakan kemasan aluminium foil yaitu selama 61 hari dan pada kemasan botol kaca yaitu selama 72 hari, sedangkan perhitungan pada ordo satu suhu $30^{\circ} \mathrm{C}$ menggunakan kemasan aluminium foil yaitu selama 116 hari dan pada kemasan botol kaca yaitu selama 194 hari. Menurut penelititan Tridiyani (2012) bahwa abon ikan marlin (Istiophorus sp.) yang dikemas dalam kemasan plastik HDPE kondisi vakum dapat bertahan selama 224 hari pada suhu $35^{\circ} \mathrm{C}, 161$ hari pada suhu $40^{\circ} \mathrm{C}$ dan 112 hari pada suhu $45^{\circ} \mathrm{C}$.

Hal ini menunjukkan bahwa kondisi kemasan vakum dapat menjaga mutu abon dengan sangat baik karena hampa udara dan tekanan yang rendah dapat membunuh mikroorganisme.

Tabel 1. Perhitungan umur simpan abon berdasarkan analisis TBA

\begin{tabular}{|c|c|c|c|c|c|c|}
\hline Kemasan & $\begin{array}{l}\text { Suhu } \\
(1 / T)\end{array}$ & Persamaan & Nilai y & K & $\ln (\mathrm{Ao})-(\mathrm{At})$ & Umur Simpan (hari) \\
\hline \multirow{3}{*}{$\begin{array}{l}\text { Aluminium } \\
\text { Foil }\end{array}$} & 0.0033 & \multirow{3}{*}{$y=0.0146 x+1.1291$} & 4.4720 & 0.0114 & \multirow{3}{*}{1.3302} & 116.4300 \\
\hline & 0.0032 & & 4.1554 & 0.0157 & & 84.8397 \\
\hline & 0.0031 & & 3.8585 & 0.0211 & & 63.0443 \\
\hline \multirow{3}{*}{ Botol Kaca } & 0.0033 & \multirow{3}{*}{$y=0.0211 x+1.1564$} & 4.8238 & 0.0080 & \multirow{3}{*}{1.5576} & 193.8257 \\
\hline & 0.0032 & & 4.3682 & 0.0127 & & 122.8918 \\
\hline & 0.0031 & & 3.9416 & 0.0194 & & 80.2215 \\
\hline
\end{tabular}

\section{KESIMPULAN}

Pendugaan umur simpan dinilai dari perlakuan terbaik dan korelasi tertinggi pada analisis ketengikan TBA (thiobarbituric acid) abon ikan menggunakan kemasan botol kaca pada ordo nol dan ordo satu. Perhitungan model arrhenius abon ikan yang dikemas aluminium foil menghasilkan umur simpan paling lama yaitu 116 hari dalam suhu $30{ }^{\circ} \mathrm{C}$. Dengan persamaan $y=-3001.9 x+5.4353$ Perhitungan model Arrhenius pada abon yang dikemas botol kaca menghasilkan umur simpan paling lama yaitu 194 hari apabila disimpan dalam suhu 30c dengan persamaan $y=-4312.3 x+9.4082$

\section{DAFTAR PUSTAKA}

Bray, C. 2001. Dictionary of Glass: Materials and Techniques. University of Pennsylvania Press, Philadelphia

Buckle, K.A., R.A. Edwards, G.H. Fleet dan M. Wootton. 2007. Ilmu Pangan. Diterjemahkan Oleh Hari Purnomo dan Adiono. Penerbit. Universitas Indonesia, Jakarta.

Fardiaz, S. 1992. Mikrobiologi Pangan 1. Gramedia Pustaka Utama, Jakarta.

Fachruddin. 1997. Membuat Aneka Abon. Kanisius, Yogyakarta.

Pengaruh Kemasan Aluminium Foil Dan Botol Kaca Terhadap Umur Simpan Abon Ikan Tongkol (Euthynnus Affinis) Dengan Pendekatan Metode Arrhenius (Wahyu Afdillah, Ismail Sulaiman, Martunis)

Jurnal Ilmiah Mahasiswa Pertanian Unsyiah, Vol. 3, No. 3, Agustus 2018: 185-193 
Huthaimah, Yusriana, Martunis. 2017. Pengaruh Jenis Ikan dan Metode Pembuatan Abon Ikan terhadap Karakteristik Mutu dan Tingkat Penerimaan Konsumen. Jurnal Ilmiah Mahasiswa Pertanian 2(3): 244-254.

Karyono dan Wachid. 1982. Usaha Abon Ikan, Jakarta

Rosalina, Y., Alnopri, dan Prasetyo. 2009. Disain Kemasan Untuk Meningkatkan Nilai Tambah Madu Bunga Kopi Sebagai Produk Unggulan Daerah. Jurnal Agroindustri 2(9): 8-13.

Soekarto, ST, 1985. Penilaian Organoleptik Untuk Industri. Bharata Karya Aksara, Jakarta.

Tridiyani, A. 2012. Perubahan Mutu Abon Ikan Marlin (Istiophorus sp.) Kemasan Vakum Non Vakum pada Berbagai Suhu Penyimpanan dan Pendugaan Umur Simpannya. [Skripsi]. Departemen Teknologi Hasil Perairan, Fakultas Perikanan dan Ilmu Kelautan, Institut Pertanian Bogor, Bogor.

Widawati, L. dan Efrianti, S. 2015. Preferensi Panelis dan Efektivitas Penggunaan Bahan Penstabil Terhadap Mutu Sambal Hijau Tempoyak. Jurnal Aplikasi Teknologi Pangan 4(1): 42-47.

Pengaruh Kemasan Aluminium Foil Dan Botol Kaca Terhadap Umur Simpan Abon Ikan Tongkol (Euthynnus Affinis) Dengan Pendekatan Metode Arrhenius (Wahyu Afdillah, Ismail Sulaiman, Martunis)

Jurnal Ilmiah Mahasiswa Pertanian Unsyiah, Vol. 3, No. 3, Agustus 2018: 185-193 